\title{
Article
}

https://doi.org/10.11646/phytotaxa.402.6.1

\section{Four highland species of Galianthe (Rubiaceae: Spermacoceae) with restricted distribution in South America: conservation assessment and complete descriptions}

\author{
JAVIER E. FLORENTÍN ${ }^{1 *}$, MARIELA NUÑEZ FLORENTIN ${ }^{1} \&$ JOSÉ FLORIANO BAREA PASTORE 2 \\ ${ }^{I}$ Instituto de Botánica del Nordeste (CONICET-UNNE), Sargento Cabral 2131, c.c. 209, C.P. 3400. Corrientes, Argentina \\ ${ }^{2}$ Herbarium. Universidade Federal de Santa Catarina, Campus de Curitibanos, Rodovia Ulisses Gaboardi, km 3, Curitibanos, Santa \\ Catarina, Brazil \\ *Author for correspondence: florentinjaviere@gmail.com
}

\begin{abstract}
Full descriptions of four Galianthe species, complemented by new data on fruits and seed characters are presented. These species occur at 500-3000 m elevations: G. gertii and G. reitzii in southeastern Brazil; G. guaranitica in eastern Paraguay and central-western Brazil; and G. boliviana in the sub-Andean region of northern Bolivia and southern Peru. Conservation status, with comments on distribution, is provided for three of them and is reassessed for one. The lectotypification of $G$. guaranitica is discussed.
\end{abstract}

Keywords: emended descriptions, endemism, morphology, Spermacoce clade, taxonomy

\section{INTRODUCTION}

Galianthe Grisebach (1879: 156) is a neotropical genus of 55 species, positioned in the Spermacoce clade of the tribe Spermacoceae (Rubiaceae, Rubioideae; Kårehed et al. 2008, Cabral 2009). The genus is characterized by an erect habit, xylopodium or taproot, the generally distylous flowers arranged in lax thyrsoid inflorescences, bifid style, 2-carpellate ovary, longitudinally dehiscent fruit, with dehiscent valves or indehiscent mericarps, plano-convex or complanate seeds and the basic chromosome numbers of $x=8,12,14,15$ (Cabral \& Bacigalupo 1997, Cabral 2009). Its species are found in open savanna formations, locally known as rocky outcrops, flooded areas, different types of cerrado, and campos de altitude (high elevation open fields) (Florentín et al. 2017a, 2018).

After Grisebach (1879) described the genus, Galianthe was treated as a section of Borreria or Spermacoce (Schumann 1888, Kuntze 1898, Chodat \& Hassler 1904, Moore 1904, Standley 1931, Smith \& Downs 1956, Porto et al. 1977, Galati 1988), until 1991 when Cabral (1991) rehabilitated the genus for numerous South American species based on morphological evidence. This proposal was not accepted by certain authors, such as Govaerts (1996) and Terrel \& Wunderlin (2002), who kept treating Borreria and Galianthe as synonyms under Spermacoce. But Cabral's point of view was corroborated years later by studies involving different disciplines such as: citogenetic (Daviña \& Cabral 1991), palynology (Pire \& Cabral 1992) and phylogeny (Dessein 2003). Galianthe was taxonomically revised by Cabral and Bacigalupo (1997) and Cabral (2009) who proposed to divide the genus into two subgenera: Galianthe subgen. Galianthe, and G. subgen. Ebelia E.L. Cabral \& Bacigalupo (1997: 859). Most of the species of the genus are included in the subgen. Galianthe, with 41 South American species, and are characterized by capsules with dehiscent valves, seeds with winged margins, an erect habit, non-winged stems, distylous flowers, pollen with a double reticulum, and chromosome number $\mathrm{x}=8$ (Cabral 2009). Galianthe subgen. Ebelia comprises 14 species, ranging from southern Mexico to northern Argentina. The species of this subgenus are characterized by capsules with indehiscent mericarps, seeds with non-winged margins, variable habit, winged stems, distylous or homostylous flowers, pollen with a double or simple reticulum, and chromosome numbers $\mathrm{x}=12,14,15$ (Cabral \& Bacigalupo 1997, Florentín et al. 2017b).

As explained above, fruit and seeds characters, especially type of dehiscence, are important diagnostic characters for the subgeneric delimitation (Cabral \& Bacigalupo 1997, 2000, Cabral 2005, 2009); however, despite recent taxonomic advances in the study of Galianthe, some species lack this information. Therefore the descriptions of four 
species are here complemented by new data on fruit and seed characters, as well as illustrations and photographs: $G$. boliviana E.L. Cabral (2005: 142), G. gertii E.L. Cabral (1993: 13), G. guaranitica (Chodat \& Hassler 1904: 186) E.L. Cabral (1991: 244), and G. reitzii E.L. Cabral (in Cabral \& Bacigalupo 2000: 124).

Only the 10 percent of the Galianthe species were assessed for conservation status (Zappi et al. 2013, Carmo et al. 2016, Florentín et al. 2017a, Florentín et al. 2017b), and considering that most of them are of restricted distribution in South America, they are in need of a conservation assessment which is thus here provided.

\section{MATERIAL AND METHODS}

Descriptions were prepared by analyzing living plants (G. reitzii) and specimens (G. boliviana, G. gertii, and $G$. guaranitica) from the collections deposited at the herbaria: AS, B, BOLV, CTBS, CTES, COR, EFC, F, FCQ, FLOR, G, HBG, HBR, HUEFS, HUFU, ICN, IRAI, JOI, K, LIL, LPB, MBM, MO, N, NY, R, RB, SI, SJRP, SPF, UEC, UPCB, US (acronyms according to Thiers 2018). Digital images were acquired from JSTOR Global Plants (http://plants.jstor. org) indicated in the manuscript as [photo!] after the herbarium acronym and barcode (in brackets). For type specimens examined directly from visits to the herbaria an exclamation mark is given after the herbarium acronym and barcode. Fruit and seeds were dried by the critical-point method and sputter-coated with gold-palladium for scanning electronic microscopy SEM study. SEM images were captured using the JEOL 5800 LV SEM (JEOL Ltd., Tokyo, Japan) at the Universidad Nacional del Nordeste, Corrientes, Argentina. Fruit and seed characters of living and pressed specimens were examined with a stereomicroscope (SM) and measured with a digital caliper.

For the analysis of the species distribution, specimens were georeferenced using Google Earth Pro (2018) version 7.3.2 and plotted in DIVA-GIS (Hijmans 2015). Since much of our study is based on herbarium material, conservation status of the species was assessed by range size (criterion B), following the IUCN (2014) methodology version 3.1. Using the GeoCAT (Geospatial Conservation Assessment Tool, Bachman et al. 2011), available at http://geocat.kew. org/, the extent of occurrence (EOO) and area of occupancy (AOO) were calculated for each species, using a grid size of ca. $2 \mathrm{~km}$ (cell area of $4 \mathrm{~km}^{2}$ ).

Information concerning the habitat and flowering period was compiled from herbarium labels and personal observations in the field.

\section{RESULTS}

\section{Taxonomy}

Galianthe boliviana E.L.Cabral (2005: 142, fig. 1)

Type:-BOLIVIA. La Paz: Prov. Inquisivi, Cerro Aguada, 2500-2800 m, 22 November 1991, M. Lewis 40645 (holotype: LPB [0000936] (photo!); isotype: MO. (Figs. 1, 2A-C, 3 A-E).

Subshrubs or perennial herbs, up to $1 \mathrm{~m}$ tall. Stems decumbent, subquadrangular, narrowly winged, glabrous. Stipular sheath 3-5 mm long, pilose; fimbriae 5-7, glabrous, 1.8-3.7 mm long. Leaves opposite; blades elliptic, 20-40 × 7-12 $\mathrm{mm}$, acute at base, acute or acuminate at apex, minutely scabrous or glabrescent on both surfaces, discolorous, with 34 , slightly-curved subparallel secondary veins on each side of midrib. Inflorescences cymose, with condensed subunits, partial inflorescences fasciculate and congested, terminal on main and secondary branches. Flowers 4-merous, sessile to subsessile, distylous. Hypanthium obconic, $1 \mathrm{~mm}$ long, glabrous. Calyx lobes slightly unequal, in opposite pairs, the two larger ones ca. $1.7 \mathrm{~mm}$ long, the shorter ones ca. $1.2 \mathrm{~mm}$ long, triangular, glabrous on both sides, margin strigulose, with minute colleters between the lobes. Corolla infundibuliform, white or pale pink, external side papillose at apices of corolla lobes, inner side: ring of thicker and longer moniliform trichomes on the corolla lobes, and a ring of shorter and thinner moniliform trichomes on the half of corolla tube. Long-styled flowers: corollas 4-4.2 mm long; stamens included, filaments ca. $0.2 \mathrm{~mm}$ long, anthers $1-1.2 \mathrm{~mm}$ long; style exserted, ca. $3 \mathrm{~mm}$, style branches ca. $0.4 \mathrm{~mm}$ long. Short-styled flowers: corollas $4.5-5.2 \mathrm{~mm}$ long, stamens exserted, filaments ca. $2 \mathrm{~mm}$ long, anthers ca. $1.4 \mathrm{~mm}$ long, style included, ca. $2.5 \mathrm{~mm}$ long, style branches ca. $0.75 \mathrm{~mm}$ long. Nectariferous disk entire. Capsules septicidal, subturbinate, with indehiscent mericarps, $3 \mathrm{~mm}$ long, slightly compressed laterally, strigulose, calyx lobes persistent. Seeds elliptic, 1.5-2 mm long, dark brown, ventral surface with a longitudinal groove partially covered by 
the strophiole, dorsal surface with colliculate testa, cells polygonal or nearly circular, 26-100 $\mu \mathrm{m}$ wide, anticlinal walls straight, periclinal walls concave, furrowed.

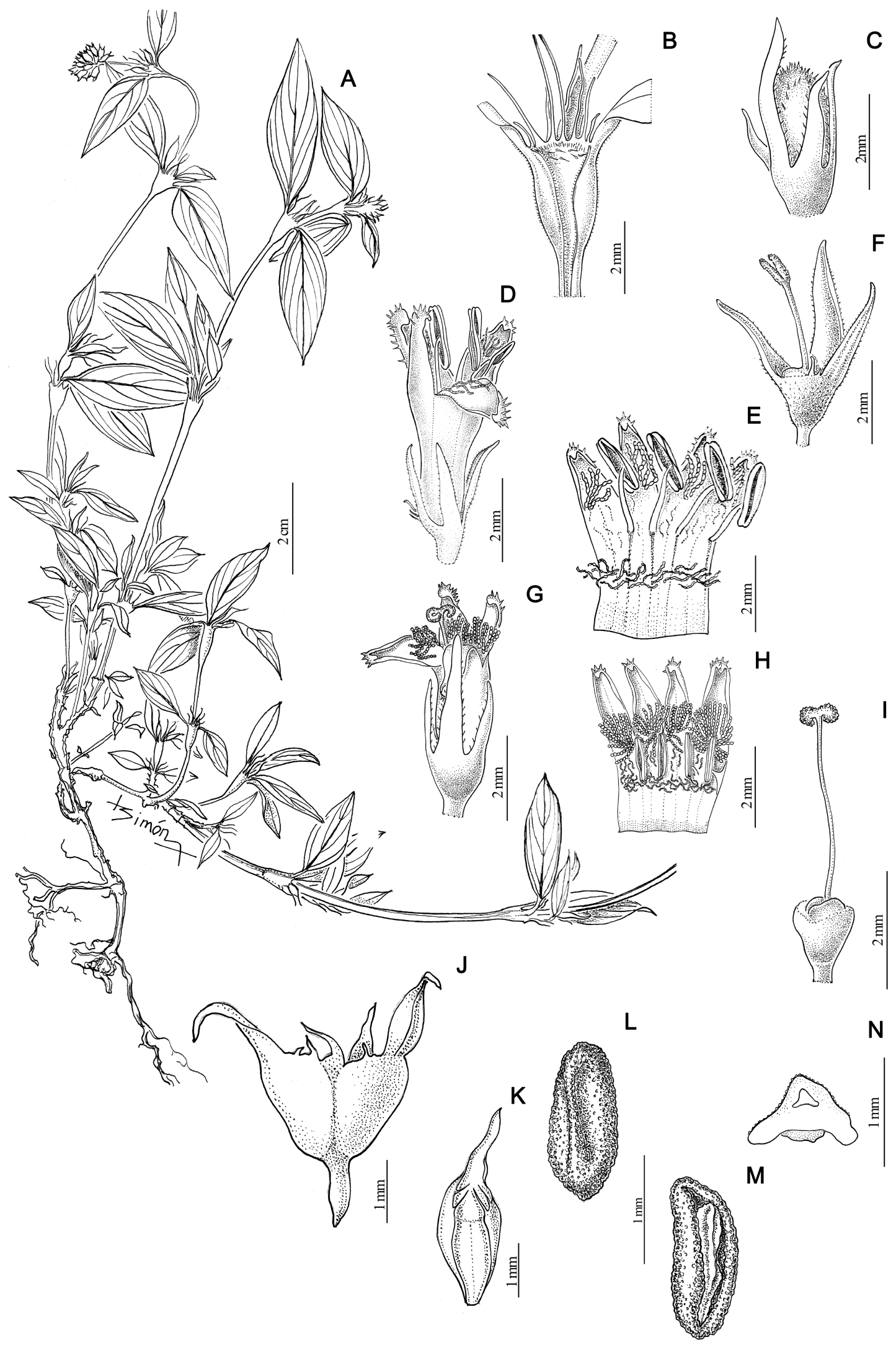

FIGURE 1. Galianthe boliviana. A. Habit. B. Stipular sheath. C. Floral bud. D-F. Short-styled flower. D. Flower. E. Opened corolla. F. Hypanthium, calyx, style, and stigma. G-I. Long-styled flower. G. Flower. H. Opened corolla. I. Hypanthium, calyx, style and stigma. J. Dehiscent fruit. K. Mericarp. L. Seed, dorsal view. M. Seed, ventral view. N. Seed, cross section. Drawn from Wood J. R. et al. 18949. Illustration by L. Simón. 


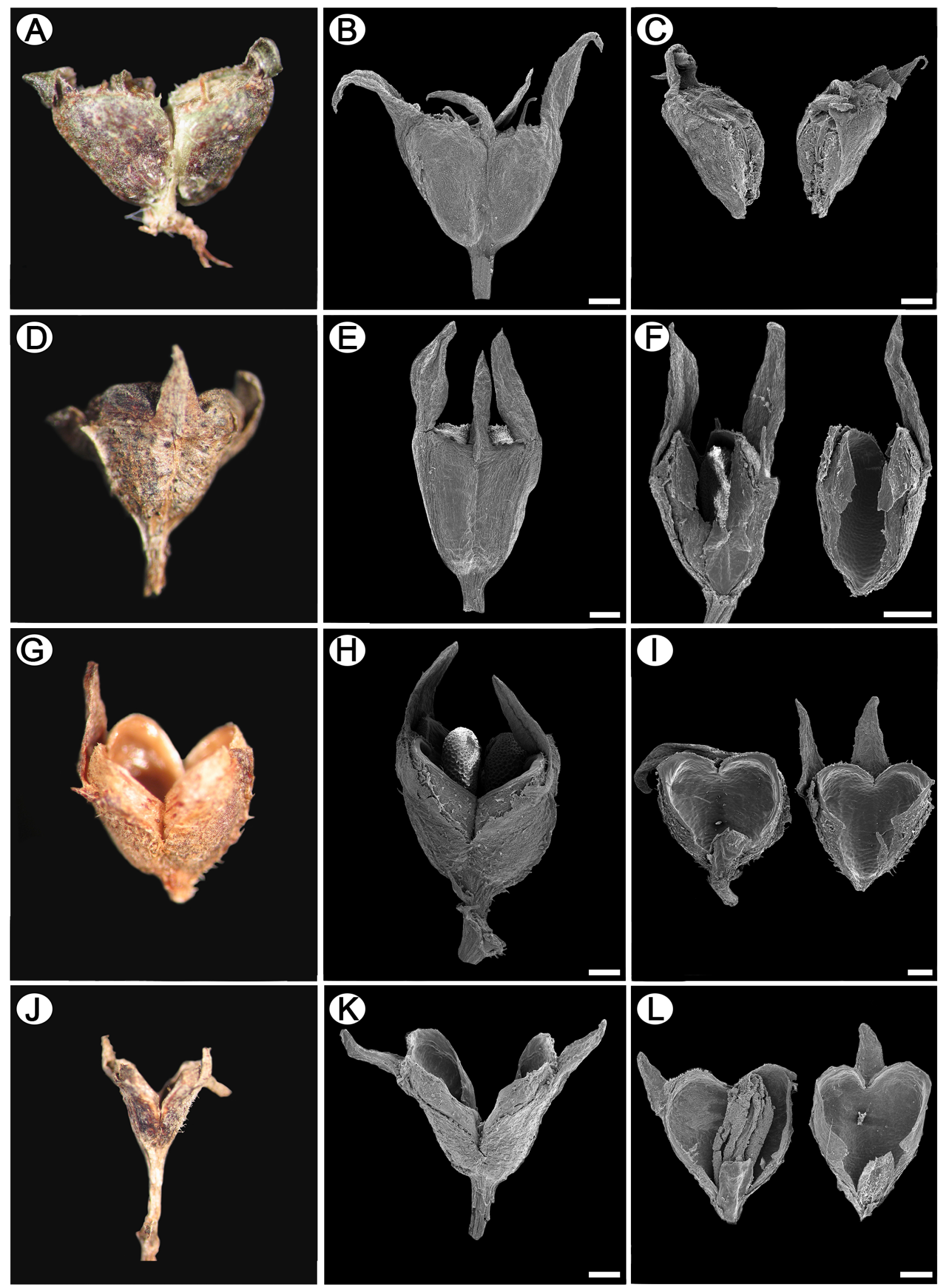

FIGURE 2. Photomicrographs of fruits in SM and SEM. A-C: Galianthe boliviana (from Wood J. R. et al. 18949). A-B. Fruit. C. Indehiscent mericarps. D-F. G. gertii (from R. Kummrow \& Silva J. M. 3397). D-E. Fruit. F: Dehiscent valves. G-I. G. guaranitica (from Schinini A. et al. 35993). G-H. Fruit. I. Dehiscent valves. J-L. G. reitzii (from Pastore et al. 5462). J-K. Fruit. L. Dehiscent mericarps. Scale bar: $500 \mu \mathrm{m}$. 

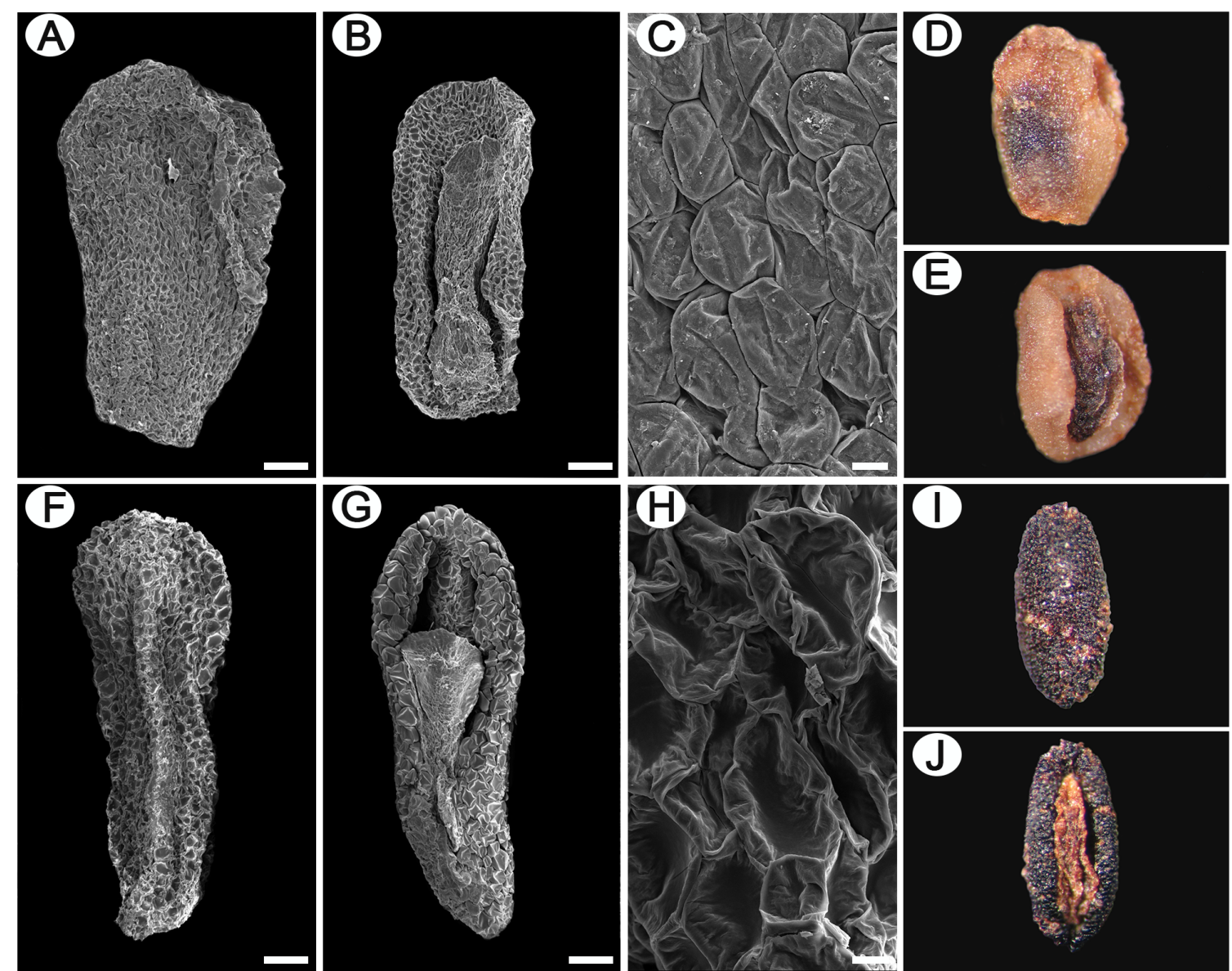

\section{G}
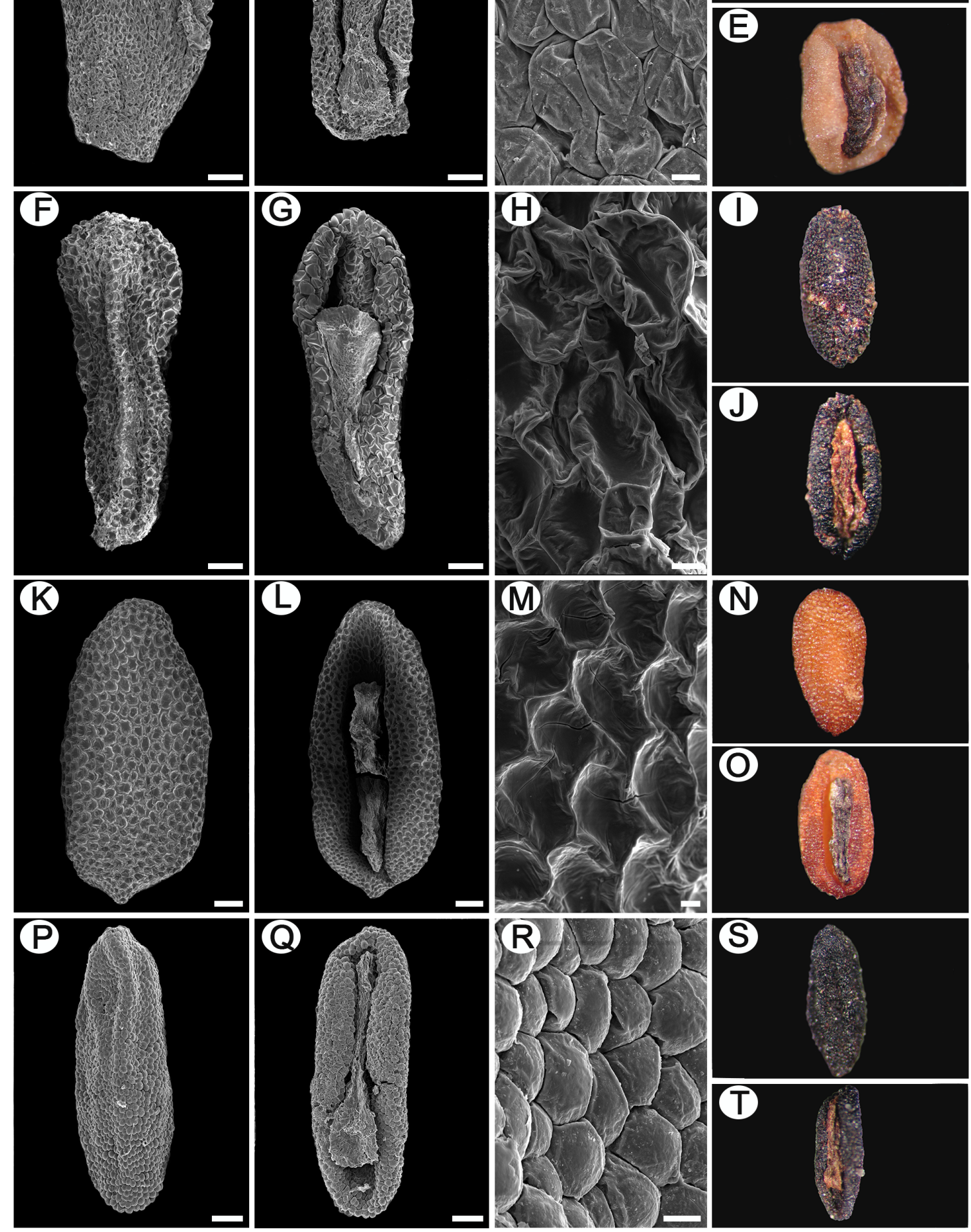

FIGURE 3. Photomicrographs of seeds in SM and SEM. A-E. Galianthe boliviana (from Wood J. R. et al. 18949). A, D. Dorsal view. B, E. Ventral view. C. Detail of testa surface. F-J. G. gertii (from R. Kummrow \& Silva J. M. 3397). F, I. Dorsal view. G, J. Ventral view. H. Detail of testa surface. K-O. G. guaranitica (from Schinini A. et al. 35993). K, N. Dorsal view. L, O. Ventral view. M. Detail of testa surface. P-T. G. reitzii (from Pastore et al. 5462). P, S. Dorsal view. Q, T. Ventral view. R. Detail of testa surface. Scale bar: A, B, F, G, K, L, P, Q: $200 \mu \mathrm{m} ; \mathrm{C}, \mathrm{H}, \mathrm{M}, \mathrm{R}: 20 \mu \mathrm{m}$. 


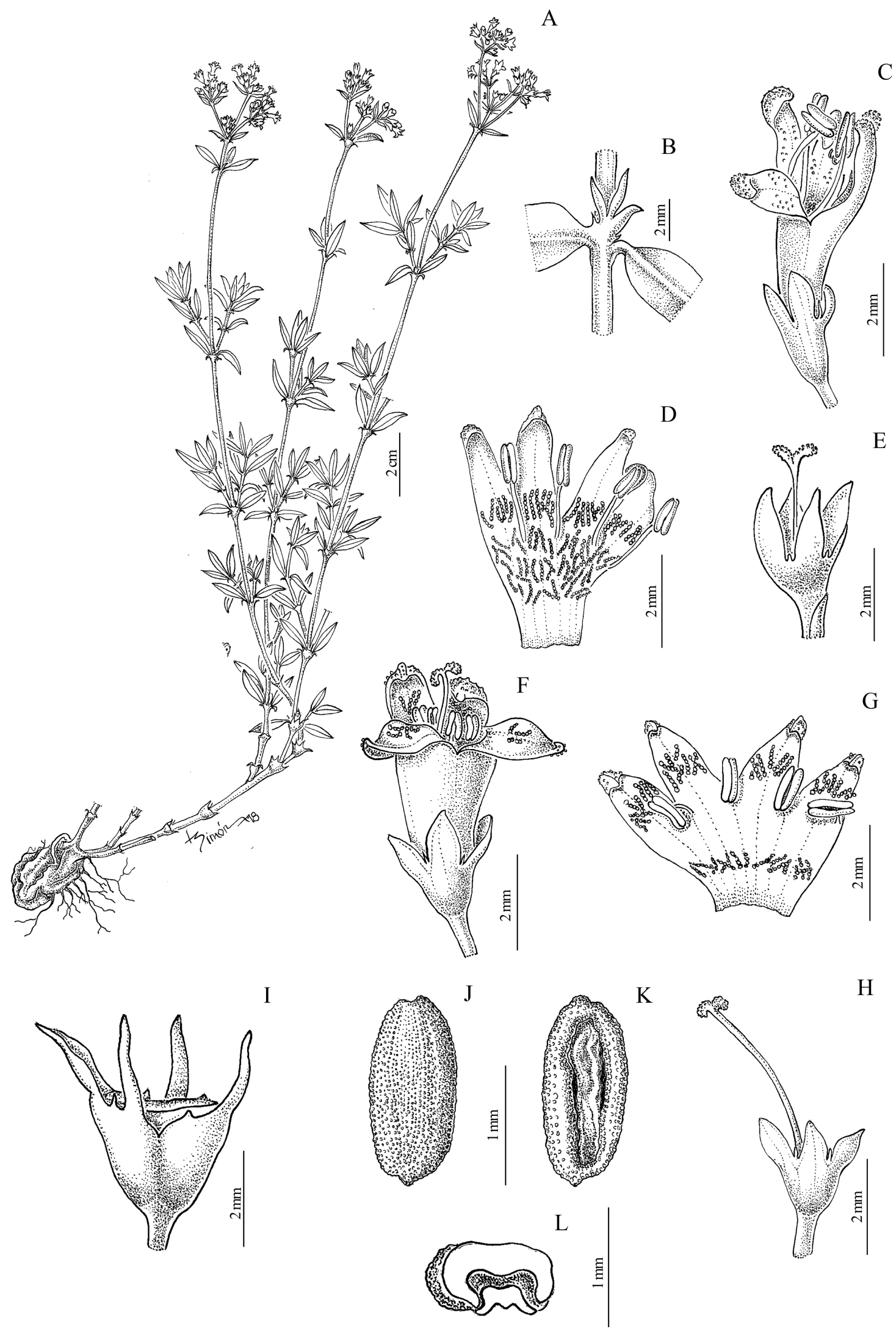

FIGURE 4. Galianthe gertii: A. Habit. B. Stipular sheath. C-E. Short-styled flower. C. Flower. D. Opened corolla. E. Hypanthium, calyx, style, and stigma. F-H. Long-styled flower. F. Flower. G. Opened corolla. H. Hypanthium, calyx, style, and stigma. I. Fruit. J. Seed, dorsal surface. K. Seed, ventral view. L. Seed, cross section. (from R. Kummrow \& Silva J. M. 3397) Illustration by L. Simón. 


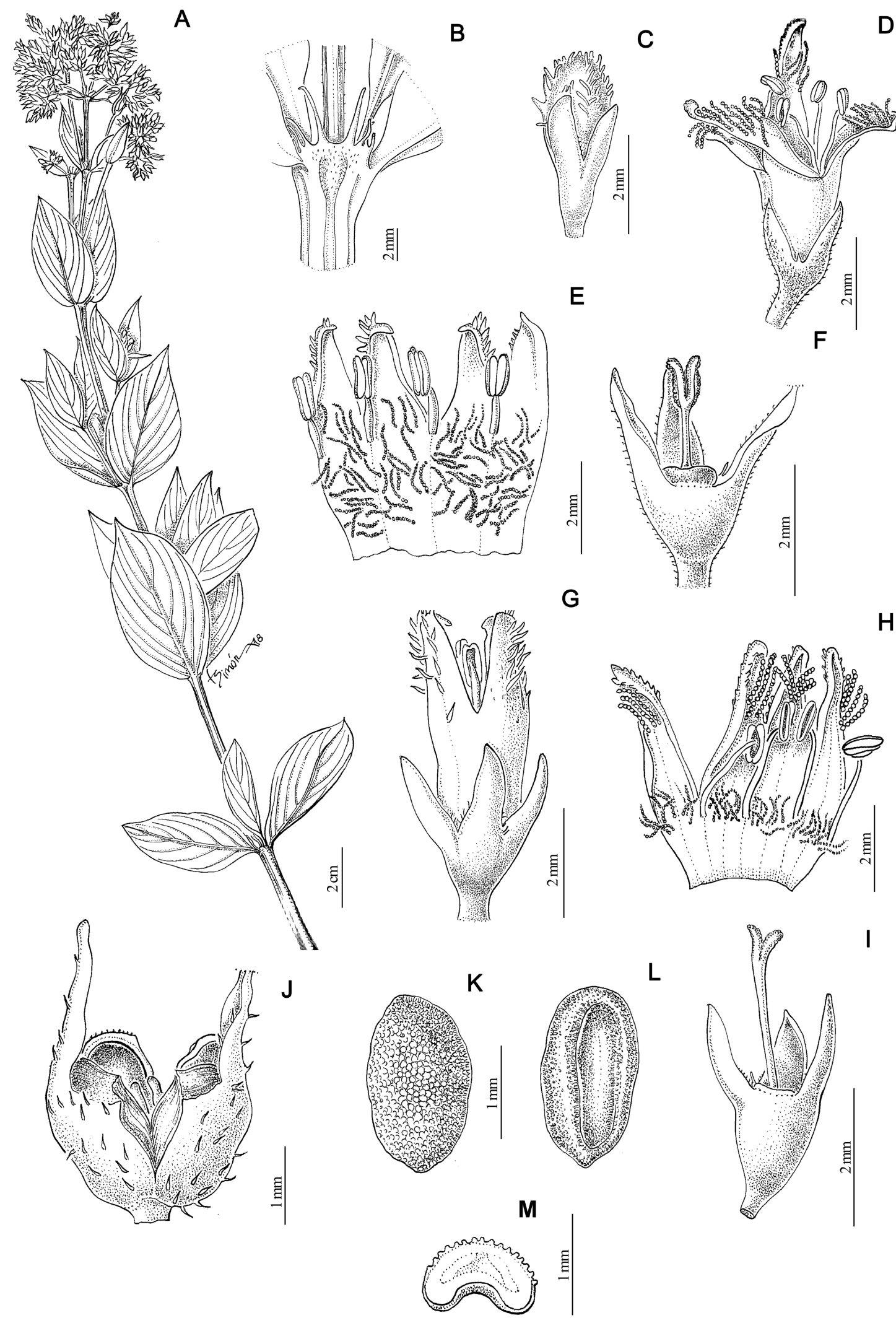

FIGURE 5. Galianthe guaranitica. A. Habit. B. Stipular sheath. C. Floral bud. D-F. Short-styled flower. D. Flower. E. Opened corolla. F. Hypanthium, calyx, style, and stigma. G-I. Long-styled flower. G. Flower. H. Opened corolla. I. Hypanthium, calyx, style, and stigma. J. Fruit. K. Seed, dorsal view. L. Seed, ventral view. M. Seed, cross section. (from Schinini A. et al. 35993) Illustration by L. Simón. 


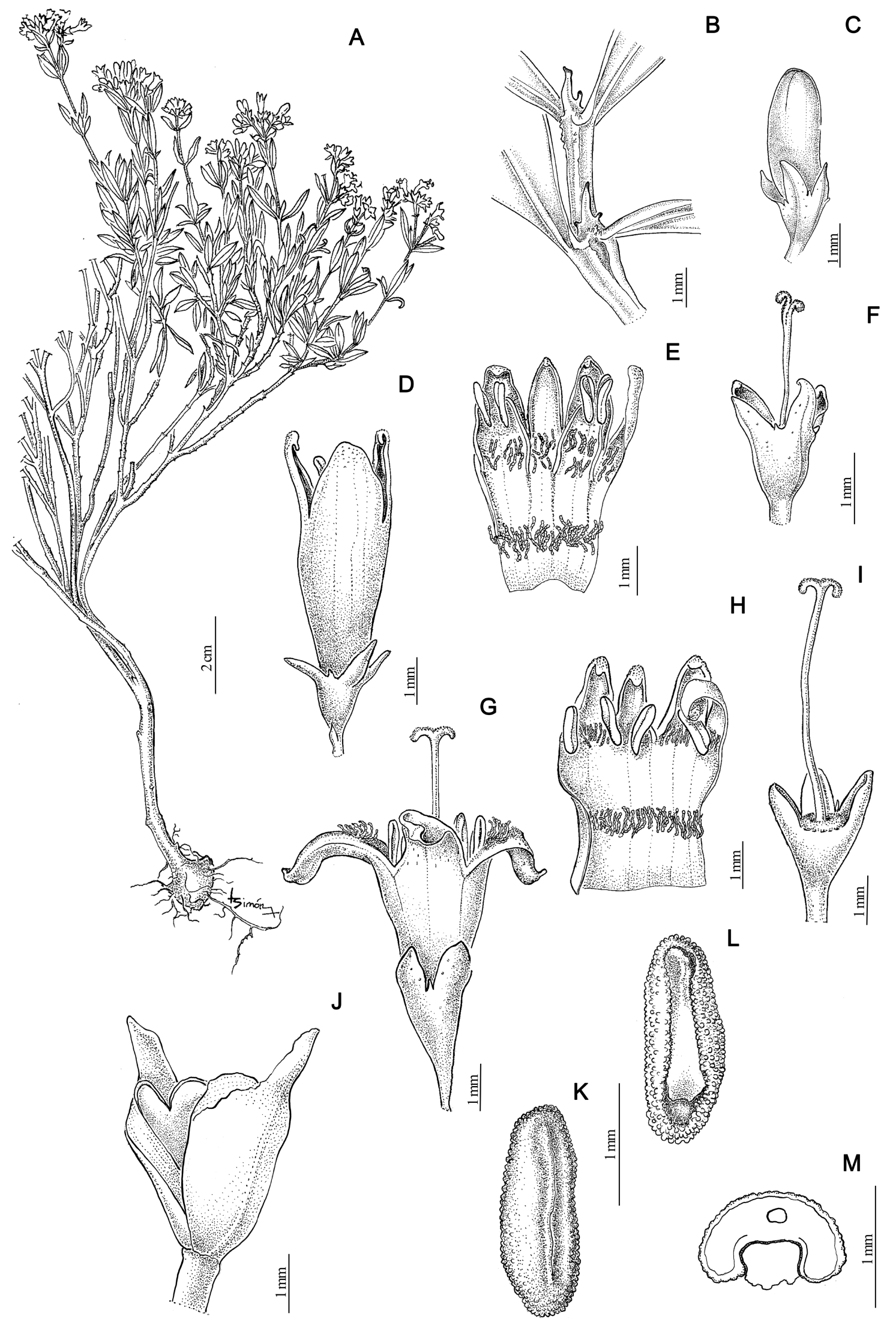

FIGURE 6. Galianthe reitzii. A. Habit. B. Stipular sheath. C. Floral bud. D-F. Short-styled flower. D. Flower. E. Opened corolla. F. Hypanthium, calyx, style, and stigma. G-I. Long-styled flower. G. Flower. H. Opened corolla. I. Hypanthium, calyx, style, and stigma. J. Fruit. K. Seed, dorsal view. L. Seed, ventral view. M. Seed, cross section. (from Pastore et al. 5462) Illustration by L. Simón. 

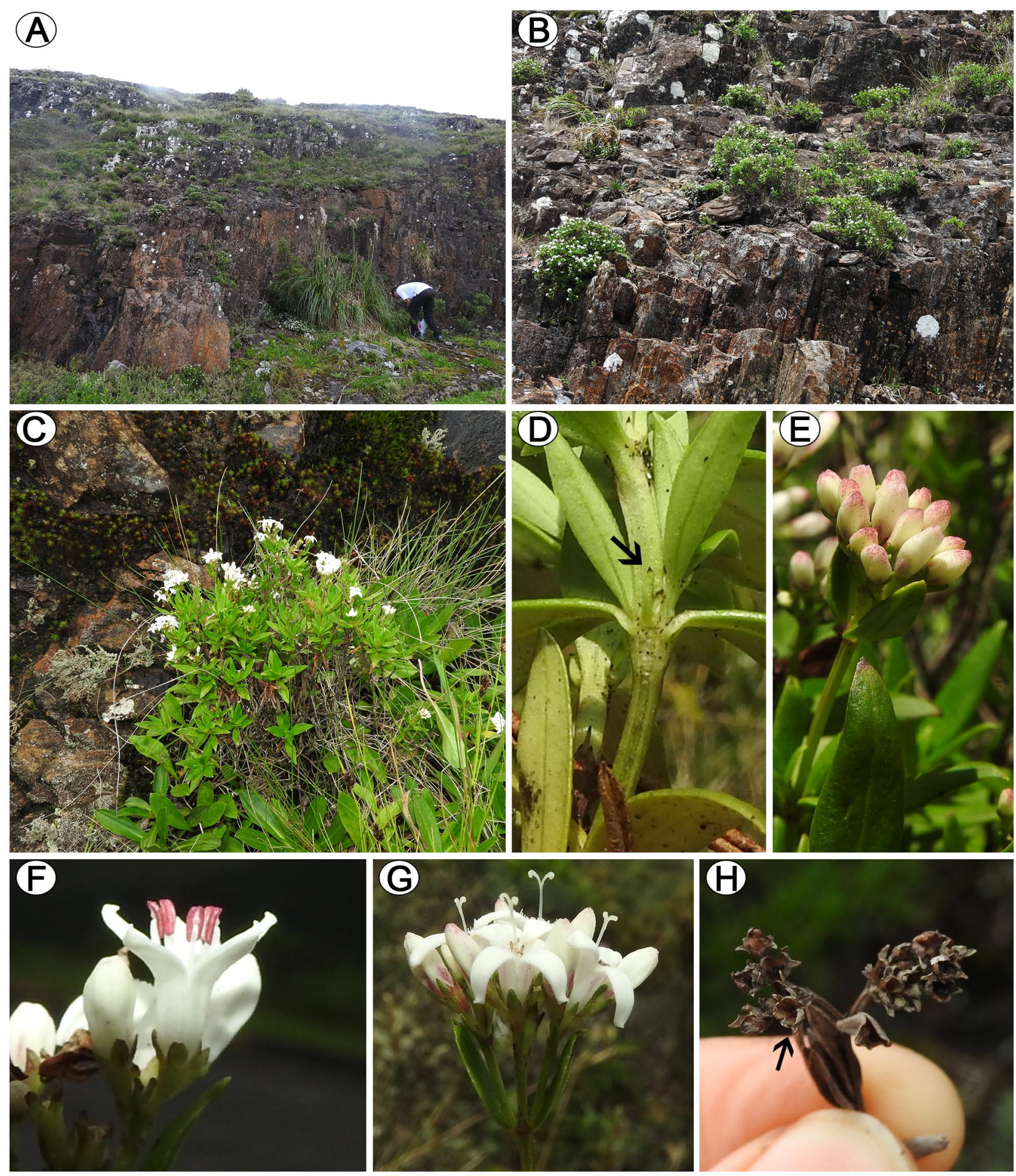

FIGURE 7. Galianthe reitzii. A, B. Habitat. C. Habit. D. Stipular sheath (arrow: the larger central lacinia). E. Floral buds. F. Short-styled flowers. G. Long-styled flower. H. Fruits (arrow: dehiscent fruit). Photographs by M. Nuñez Florentin \& J. Florentín.

Phenology:-Flowering and fruiting from November to February.

Distribution and ecology:- Occurs in Bolivia and Peru, growing mainly on eroded slopes of the Andes, restricted to high elevations, at 2800-3000 m altitude, growing especially in open forests of Alnus acuminata Kunth (1817: 20) of the Yungas (Fig. 8C).

Conservation status:-EOO: $883 \mathrm{~km}^{2}$ AOO: $12 \mathrm{~km}^{2}$. GeoCAT points: 3 . Cell size: $4 \mathrm{Km}^{2}$. IUCN Assessment: Endangered (EN). According to the area of occupation (AOO), the species is classified as EN according to criteria B: B2ab (ii,iii). Only three populations of $G$. boliviana were recorded, all restricted to the sub-Andean foothills of the provinces of Inquisivi and Bautista Saavedra (La Paz, Bolivia) and Quispicanchi (southern Peru). The results of 
our conservation assessment differ regarding the threshold of the B criterion for a species to be considered EN (EOO $<5000 \mathrm{Km}^{2}$; AOO $<500 \mathrm{Km}^{2}$ ). Species are often habitat specialists and will occur throughout the EOO, that may contain unsuitable or unoccupied habitats (IUCN 2014). According to the AOO, the species is classified as EN. The AOO is severely fragmented, with the species found in only five localities restricted to high-elevation environments at 2800-3000 m altitude. The region of its occurrence in Peru is subject to degradation by the mining activities that threaten its survival.

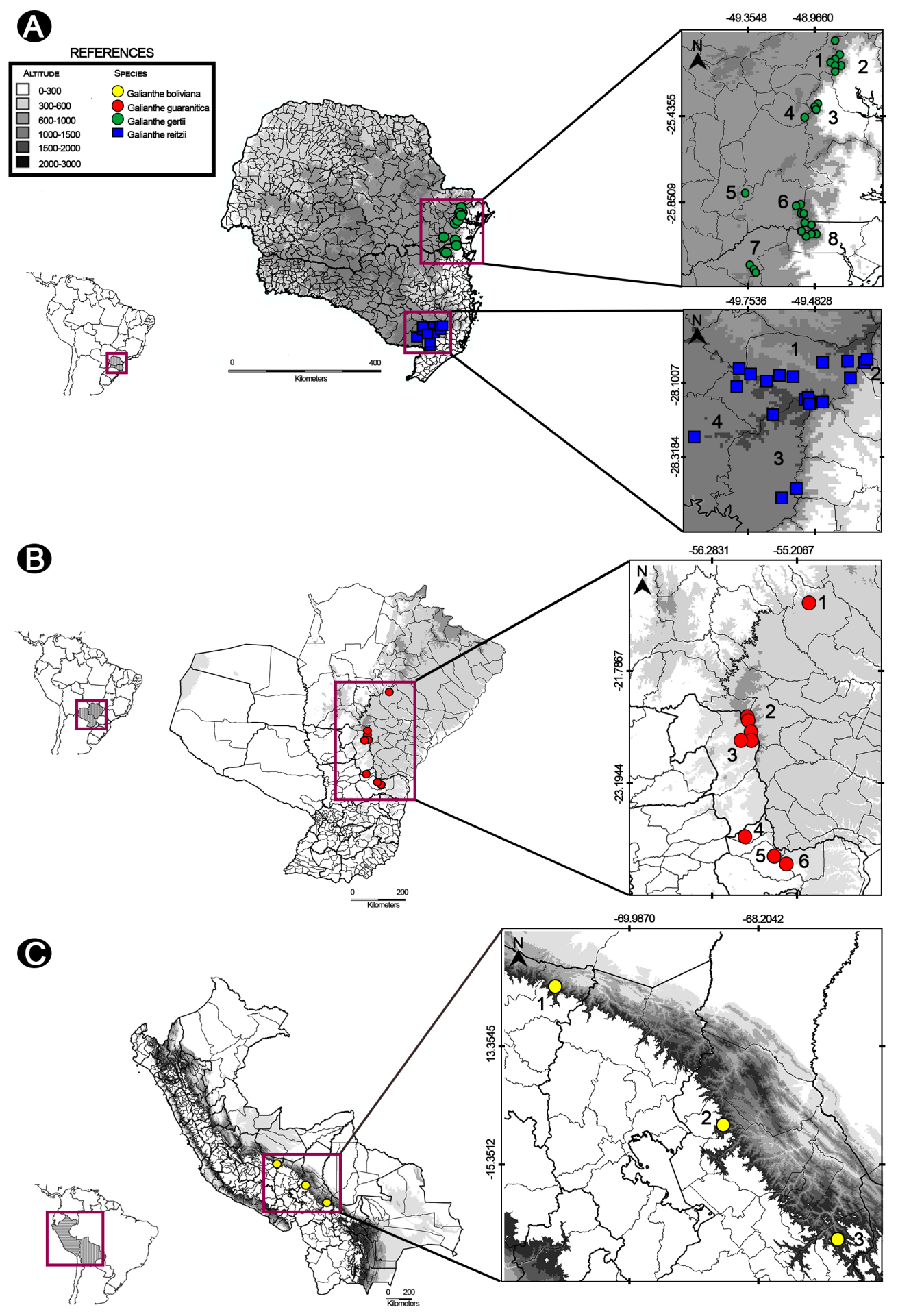

FIGURE 8. Distribution map of Galianthe species. A. Galianthe gertii (green circles). Municipalities: 1: Campina Grande do Sul. 2: Antonia. 3: Morretes. 4: Piraquara. 5: Mandirituba. 6: Tijucas do Sul. 7: Campo Alegre. 8: Garuva; G. reitzii (blue squares). Municipalities: 1: Urubici. 2: Rio Fortuna. 3: Bom Jardim da Serra. 4: São Joaquim. B. G. guaranitica (red circles). Municipalities: 1: Sidrolândia. 2: Ponta Porá. 3: Pedro Juan Caballero. 4: Itanará. 5: Villa Ygatimí. 6: Corpus Christi. C. G. boliviana (yellow circles). Municipalities: 1: Quispicanchi. 2: Bautista Saavedra. 3: Inquisivi. 
Specimens examined:-BOLIVIA. La Paz: Prov. Inquisivi, $5 \mathrm{~km} \mathrm{~N}$ of Choquetanga, $16^{\circ} 38^{\prime} \mathrm{S}, 6^{\circ} 18^{\prime} \mathrm{W}, 22$

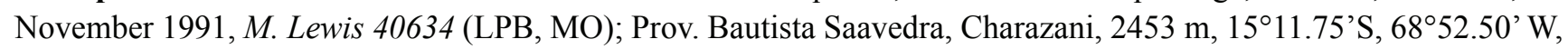
10 February 2003, J. Wood, T. Ortuño \& M. Atahuachi 18949 (BOLV). PERU. Cusco: Quispicanchis, Marcapata, 176 $\mathrm{km}$ from Cusco on road to Maldonado, Marcapata to Cocha, $13^{\circ} 25^{\prime} \mathrm{S}, 70^{\circ} 54^{\prime} \mathrm{W}, 3150 \mathrm{~m}, 8 \mathrm{March} 1991$, V. Percy Nuñez \& C. Paycarmayta $13140(\mathrm{MO})$.

\section{Galianthe gertii E.L.Cabral (1993: 13, fig. 5)}

Type:-BRAZIL. Paraná: Mun. Campina Grande do Sul, Serra Ibitiraquire, 22 January 1970, G. Hatschbach 23388 (holotype MBM!, isotypes C [10018163] (photo!), CTES [0013543]!, HBG [521683] (photo!), US [00406424] (photo!)) (Figs. 2D-F, 3F-J, 4).

Herb erect to decumbent, 20-50 cm tall. Stems tetragonal, glabrous; internodes $0.5-5.5 \mathrm{~cm}$ long. Stipular sheath 2 $\mathrm{mm}$ long, glabrous, with irregular border ending in 3-5 triangular-lanceolate fimbriae, $1.25-3.75 \mathrm{~mm}$ long, glabrous, the central one longest, glabrous, with bright spots. Leaves sessile, pseudoverticillate, with axillary brachyblasts; blades elliptic-oblong, 8-25 $\times 2-7 \mathrm{~mm}$, obtuse at base, acute at apex, subchartaceous, glabrous, discolorous, with bright dots on both sides, margin revolute, median vein depressed on the adaxial surface, prominent on the abaxial surface, secondary veins $2-3$ on each side of midrib, inconspicuous. Inflorescence terminal, thyrsoid, umbelliform, pauciflorous, shortly pedunculate. Flowers 4-merous, shortly pedicellate, distylous; hypanthium turbinate, 0.7-1.5 $\mathrm{mm}$ long, glabrous. Calyx lobes subequal, triangular, 1-1.3 mm long, glabrous, with colleters at calyx lobe sinuses. Corolla infundibuliform, white, pinkish, or lilac, external side glabrous; lobes equal to or shorter than the corolla tube, papillose at apices. Long-styled flowers: corollas 3.7-5 mm long; with a ring of thin moniliform trichomes at median portion of corolla tube inside, and a ring of thicker trichomes at the middle of corolla lobes; stamens included, filaments ca. $0.7 \mathrm{~mm}$ long, anthers $0.7-1.2 \mathrm{~mm}$ long; style exserted, ca. $4.5 \mathrm{~mm}$ long, style branches ca. $1 \mathrm{~mm}$ long. Short-styled flowers: corollas 4.5-6.2 mm long, with a fringe of moniliform hairs from the base of corolla lobes to the middle corolla tube inside, stamens exserted, filaments $1-1.7 \mathrm{~mm}$ long, anthers $1-1.2 \mathrm{~mm}$ long, style included, 2-2.7 $\mathrm{mm}$ long, style branches ca. $1 \mathrm{~mm}$ long. Nectariferous disk entire. Capsules turbinate, septicidal, with dehiscent valves, 2-2.5 mm long, calyx lobes persistent. Seeds ellipsoid, 1.5-2 mm long, blackish to dark brown, ventral surface with a longitudinal groove partially covered by the strophiole, dorsal surface foveolate, testa colliculate, cells polygonal or nearly circular, 30-110 um wide, anticlinal walls straight, periclinal walls convex.

Phenology:-Flowering from November to February, and fruiting from March to April.

Distribution and ecology:- This species occurs on rocky soils at 1000-1700 m elevation, in montane areas of southeast of Paraná and Santa Catarina states, southern Brazil,, known as High Altitude Tropical Grasslands (HTG), also referred to as campos de altitude (Fig. 8A).

Conservation status:-EOO: $2590 \mathrm{~km}^{2}$. AOO: $116 \mathrm{~km}^{2}$. GeoCAT points: 37 . Cell size: $4 \mathrm{Km}^{2}$ IUCN Assessment: Endangered (EN). Its conservation status has been classified as EN according to criteria B: B1b (ii, iii, iv) +2 b(ii,iii). G. gertii has a restricted distribution in six municipalities of the states of Paraná (Campina Grande do Sul, Antonia, Morretes, Piraquara, Mandirituba, and Tijucas do Sul) and two municipalities of Santa Catarina (Campo Alegre and Garuva). Mocochinski \& Scheer (2008) studied the floristic composition of six areas of High Altitude Tropical Grasslands (HTG) in the Serra do Mar, in the state of Paraná, citing G. gertii for three of them (Serra do Ibitiraquire, Serra da Farinha Seca, and Serra da Pedra Branca do Araraquara) and reporting biological contamination (mostly by Pinus sp.), anthropic pressure on mountain environments, and construction of telecommunication facilities as the most important threats to HTG.

Specimens examined:-BRAZIL. Paraná: Ipiranga, s.d., M. Muscon 3382 (R). Mun. Morretes, Serra Marumbi, Pico Olimpo, 10 January 1996, O. Ribas, J. Silva \& E. Barbosa 957 (CTES, MBM, SPF); Morretes, Serra Marumbi, Picada Frontal, 15 January 1950, N. Imaguirre 1734 (LIL, MBM); Mun. Morretes, Trilha Crista do Gigante, Parque Estadual do Marumbi, 17 January 2016, R.Völtz, M. Brotto \& O. Bizarro 766 (EFC); Mun. Morretes, Serra Marumbi, Picada Frontal 15 January 1950, N. Imaguirre 1734 (LIL, MBM); Morretes, Serra Marumbi, 27 February 1970, G. Hatschbach 23935 (HUFU); Mandirituba, Rio Mauricio, 23 February 1978, G. Hatschbach 41460 (US); Mun. Guaratuba, Serra de Araçatuba, Morro dos perdidos, 22 January 1999, E. Santos, L. Cãndido, M. Hassegawa \& R. Silva 727 (CTES); Mun. Guaratuba, Serra de Araçatuba, 21 January 1994, R. Kummrow \& J. Silva 3397 (CTES, MBM, JOI); Serra Capivari, 15 January 1969, G. Hatschbach \& C. Koczicki 20766 (MBM); Mun. Campina Grande do Sul, Morro Tucum, 22 December 1999, O. Ribas 2864 (HUEFS); Mun. Campina Grande do Sul, Serra Capivari 8 February 1971, G. Hatschbach 26316 (MBM, NY); Mun. Campina Grande do Sul, Serra Ibitiraquire, 21 January 1970, G. Hatschbach 23392 (MBM, US); idem, 22 January 1970, G. Hatschbach 23388 (RB, HBG); Serra de Araçatuba, 31 January 1960, G. Hatschbach 6695 (MBM, US); Campina Grande do Sul, Serra Capivari, 8 February 1971, G. Hatschbach 26316 
(MBM, NY); Pico Caratuva, 29 December 1967, G. Hatschbach 18206 (B, HBR, MBM, P). Antonina, Abrigo I, Trilha para o Pico Paraná, 4 July 2010, R. Ristow 735 (IRAI); Quatro Barras, Serra da Farinha Seca, Morro OOB, 6 December 2002, A. Mocochinski 260 (UPCB). Santa Catarina: Mun. Campo Alegre, Serra do Quiriri, Rio dos Alemães, 14 January 1998, O. Ribas, J. Cordeiro \& E. Barbosa 2276 (CTES, MBM); Morro do Iquererim, Campo Alegre, 5 February 1958, R. Reitz \& R. Klein 6426 (B, HBR, MBM, US); idem, 19 November 1992, J. Cordeiro \& E. Barbosa 932 (CTES, MBM); idem, 10 January 1958, R. Reitz \& R. Klein 6138 (B, US); idem, 5 February 1958, $R$. Reitz \& R.Klein 6426 (B, HBR, MBM, US); Morro do Campo Alegre, 21 December 1960, R. Reitz \& R. Klein 10498 (HBR).

Galianthe guaranitica (Chodat \& Hassl.) E.L.Cabral (1992 ["1991"]: 244, fig. 5). - Borreria guaranitica Chodat \& Hassler (1904: 186)

Type:-PARAGUAY. Maracayú: In campo Ypejhú, Sierra de Maracayú, December [year not indicated], E. Hassler 5594 (Lectotype, G [00436134] photo!, designated by Cabral (1991: 244); isolectotypes BM [000074141] photo!, K [000470440] photo!, MPU [022462] photo!, NY [00004536] photo!, P [00631803] photo!, S [Acc. No. 051636] photo!, UC [935183] photo!). (Figs. 2G-I, 3K-O; 5).

Subshrubs erect, 0.6-1.5 m tall, with xylopodium; stems 2-3 per plant, simple, tetragonal, glabrous or pubescent, internodes (3-)4-8 cm long. Stipular sheath extended over the separation of the leaf pair, 4-5 mm long, pilose; fimbriae 7-8, 2-6(-8) $\mathrm{mm}$ long, filiform, glabrous. Leaves pseudoverticillate, with axillary brachyblasts; blades elliptic, (30-)40-50 $\times(12-) 17-27 \mathrm{~mm}$, acute at base and at apex, glabrous, with a few scattered hairs on the veins below, with 5-6 secondary veins on each side of midrib. Inflorescence terminal, thyrsoid, congested, 2-6(-10) $\mathrm{cm}$ long, multiflorous, shortly pedunculate. Flowers 4-merous, pedicellate. Hypanthium turbinate, $1.5 \mathrm{~mm}$ long, glabrous or pilose. Calyx lobes equal, triangular-subulate, 1.5-2 mm long, glabrous, with colleters at lobe sinuses. Corolla infundibuliform, 5.5-7 mm long, white, lobes and tube of same length, glabrous ouside; corolla lobes papillose at apex. Long-styled flowers: corolla inner side with moniliform trichomes forming a ring at mouth, sparse hairs near the the base of corolla lobes; stamens included, filaments ca. $1 \mathrm{~mm}$ long, anthers 1.2-1.5 mm long; style exserted, ca. 5 $\mathrm{mm}$ long, style branches ca. $0.7 \mathrm{~mm}$ long, papillose. Short-styled flowers: corolla tube with a ring of longer, thinner moniliform trichomes in the upper half inside, and sparse, thicker trichomes on the corolla lobes; stamens exserted, filaments ca. $1.5 \mathrm{~mm}$ long, anthers ca. $1.2-1.3 \mathrm{~mm}$ long; style included, $0.5 \mathrm{~mm}$ long, style branches ca. $0.25 \mathrm{~mm}$ long, papillose. Nectariferous disk entire. Capsules subglobose, septicidal, with dehiscent valves, 3-3.5 mm long, pilose, calyx lobes persistent. Seeds ellipsoid, $2-2.5 \mathrm{~mm}$ long, dark brown, ventral surface with a longitudinal groove partially covered by the strophiole, dorsal surface with reticulate-foveolate testa, cells polygonal or nearly circular, $20-100$ um wide, anticlinal walls sinuate, periclinal walls concave.

Phenology:-Flowering and fruiting from December to April.

Distribution and ecology:- - It occurs in the state of Mato Grosso do Sul, Brazil, and eastern Paraguay, growing on sandy soils of the grassland cerrado at 500-700 m elevation (Fig. 8B).

Conservation status:-EOO: $16 \mathrm{~km}^{2}$. AOO: $44 \mathrm{~km}^{2}$. GeoCAT points: 11 . Cell size: $4 \mathrm{Km}^{2}$. IUCN Assessment: Endangered (EN). Its conservation status has been classified as EN according to criteria B: B2ab(ii,iv), c(iii). In Brazil, this species is found in the municipality of Sidrolândia, Mato Grosso do Sul. In Paraguay, its populations were recorded from Amambay (municipality of Juan Pedro Caballero) and Canindeyú (municipalities of Itanará, Villa ygatimí, and Corpus Christi). In the latter, it is found in the Reserva de la Biosfera del bosque Mbaracayú, a protected area. The conservation status of EN for the species was applied because it is found in only five localities, most of them known for their extensive soy and manioc plantations and livestock raising, making the Reserva de la Biosfera del bosque Mbaracayú especially important for its preservation as the only protected area in the region.

Notes:-Chodat and Hassler (1904) described Borreria guaranitica, basionym of Galianthe guaranitica, citing the gathering Hassler 5594, without indicating the herbarium of deposit. A specimen of this gathering at $\mathrm{G}$ was cited by Cabral (1991) as the holotype. According to Art. 9.23 of the Code (Turland et al. 2018), Cabral (1991) citation is an inadvertent lectotypification.

Specimens examined:-PARAGUAY. Amambay: Colonia Estrella, $45 \mathrm{~km}$ NW de P.J. Caballero, $22^{\circ} 18^{\prime} \mathrm{S}$,

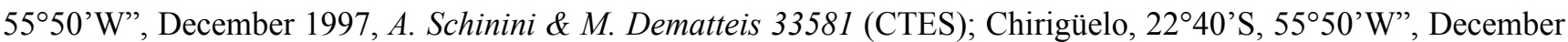
1997, A. Schinini \& M. Dematteis 33496 (CTES); 6 km F from Pedro Juan Caballero, May 1981, S. Tadashi 133 (MO); idem, January 1934, T. Rojas 6596 (AS, CTES, MO); camino a colonia Estrella, $1 \mathrm{~km} \mathrm{~W}$ del Hito 1/44, s.d, A. Schinini \& M. Dematteis 33626 (FCQ); alrededores de P.J. Caballero, ruta 5, camino a Cerro Corá, 8 March 2002, A. Schinini, M. Dematteis, R. Duré \& M. Quintana 36057 (CTES); Ea. San Luis, $11 \mathrm{~km} \mathrm{~W}$ del puesto Aquidauna (Brasil) límite con Paraguay, 7 March 2002, A. Schinini, M. Dematteis, R. Duré \& M. Quintana 35990 (CTES). Canindeyú: In campo 
Ypejhú, Sierra de Maracayú, December 1903, E. Hassler 5594 (G, NY, K); Maracayú Natural Reserve, 24¹1'16“S, 55¹6’45'W, January 1998, E. Zardini \& M. Vera 47903 (AS, CTES, MO); idem, E. Zardini \& M. Vera 47874 (AS, CTES, MO). Idem, 26 March 1999, E. Zardini \& I. Chaparro 50683 (AS, CTES, MO).

BRAZIL. Mato Grosso do Sul: Mun. Sidrolândia, Santa Fe, 23 January 1971, G. Hatschbach 26028 (CTES, MBM, NY, US).

Galianthe reitzii E.L.Cabral (2000: 124, fig. 3)

Type:-BRAZIL. Santa Catarina. Mun. Urubici, Serra do Oratório, Bom Jardim, 9 December 1958, R. Reitz \& R. M. Klein 7688 (holotype HBR; isotypes: BR [0000005639816], G [Acc. No. 8202/20]!, K [00470429] photo!, M [0187444] photo!, US [01106442] photo!) (Figs. 2J-L, 3P-T, 6, 7).

Subshrubs $0.2-1 \mathrm{~m}$ tall, erect, with xylopodium. Stems subtetragonal to tetragonal, multi-branched, glabrous, proximal nodes with deciduous foliage, internodes 2-10 mm long. Stipular sheath 1-1.5 mm long, pilose, with the central fimbria subulate, $1.5-2 \mathrm{~mm}$ long, and two shorter, lateral fimbriae, $0.5-1 \mathrm{~mm}$ long, glabrous, with apical colleters. Leaves pseudoverticillate, with leafy brachyblasts, sessile; blades linear or lanceolate, 10-24 $\times 5 \mathrm{~mm}$, acute at base and at apex, chartaceous, glabrous, single-veined, margin recurved, discolorous. Inflorescence thyrsoid, pauciflorous, congested, 20-40 mm long, shortly pedunculate. Flowers 4(5)-merous, sessile to subsessile, distylous. Hypanthium turbinate, $2 \mathrm{~mm}$ long, glabrous, with small pink spots. Calyx lobes equal, triangular-subulate, 1.5-2 mm long, glabrous, with a single colleter at each lobe sinus. Corolla infundibuliform, 5-8 mm long, white, glabrous outside, papillate, lobes shorter than the corolla tube, inner side with trichomes at base of the corolla lobes and in the inferior third of the corolla tube, tube $4 \mathrm{~mm}$ long, lobes triangular, 3-5 $\mathrm{mm}$ long. Long-styled flowers: stamens included, filaments ca. $1 \mathrm{~mm}$ long, anthers ca. $1.5 \mathrm{~mm}$ long; style exserted, ca. $6 \mathrm{~mm}$ long, style branches $2.5 \mathrm{~mm}$ long. Short-styled flowers: stamens exserted, filaments ca. $3 \mathrm{~mm}$ long, anthers ca. $1.5 \mathrm{~mm}$ long; style included, ca. $2.5 \mathrm{~mm}$ long, style branches $2 \mathrm{~mm}$ long. Nectariferous disk entire. Capsules turbinate, septicidal, with dehiscent valves, $3 \mathrm{~mm}$ long, calyx lobes persistent. Seeds elliptic, 1.5-2 mm long, blackish to brown, ventral surface with a longitudinal groove partially covered by the strophiole, dorsal surface with colliculate testa, cells circular, $25-52 \mu \mathrm{m}$ wide, anticlinal walls convex, periclinal walls convex, furrowed.

Notes:-Galianthe reitzii E.L. Cabral (2000: 124) was treated by Delprete (2004) as a juvenile, herbaceous form of G. gertii E.L. Cabral (1993: 14), and the two taxa were treated as synonymous. However, Galianthe reitzii differs from $G$. gertii because it is subshrubs habit, up to $1 \mathrm{~m}$ tall (vs. herb habit, up to $50 \mathrm{~cm}$ tall), with xylopodium (vs. without xylopodium), internodes $0.2-1 \mathrm{~cm}$ long (vs. $1-5.5 \mathrm{~cm}$ long), stipular sheath with a central fimbria and two shorter lateral with apical colleters (vs. stipular sheath with 3-5 fimbriae, without apical colleters), leaves singleveined, vein prominent on the abaxial surface (vs. median vein prominent on the abaxial surface, and secondary veins $2-3$ on each side of midrib, inconspicuos), corolla always white (vs. white, pinkish, or lilac), long-styled and short-styled flowers with the same inner pubescence, trichomes at base of the corolla lobes and in the inferior third of the corolla tube (vs. long-styled flower with a ring of trichomes at median portion of corolla tube inside and a ring of trichomes at the middle of corolla lobes, and short-styled flower with fringe of moniliform hairs from the base of corolla lobes to the middle corolla tube). Therefore the two taxa are here treated a separate species.

Phenology:-Flowering and fruiting from December to April.

Distribution and ecology:- It is endemic to the state of Santa Catarina in southeastern Brazil, growing on sandstone rocks at 1000-1822 m altitude (Fig. 8A). It is found in the São Joaquim National Park, in the Serra Geral mountain range, in large areas of high-altitude grasslands. This locality is considered the coldest region of Brazil, the only place in the country with occurrence of snowfalls (Ibama 1998).

Conservation status:-EOO: $1582 \mathrm{~km}^{2}$. AOO: $68 \mathrm{~km}^{2}$. GeoCAT points: 20 . Cell size: $4 \mathrm{Km}^{2}$. IUCNAssessment: LC (Least concern). In a recent study by Külkamp et al. (2018) that described and mapped the distribution of the endemic flora of the subtropical highland grasslands (SHG), G. reitzii and its conservation status, were based on nine records, and was assessed for the first time. In the present study, we reassessed its conservation status, expanding the number of records to 20 . Our assessment confirmed its status as EN, but because the species is found within a protected area (São Joaquim National Park), it should be considered as LC.

Specimens examined:-BRAZIL. Santa Catarina: Urubici, Cuesta a Bom Jardim da Serra, ca. 1000 m, 20 January 1975, L. Ahumada \& U. Eskuche 3361 (CTES, N, SI); Morro da Igreja, 1822 m, 3 January 1949, R. Reitz 2969 (B, HBR, US); Morro da Igreja, 18 January 1994, J. Stehmann \& A. Vieira 1295 (UEC); Urubici, Morro da Igreja, 4 December 1992, D. Falkenberg \& F. Silva Filho 5901 (FLOR, ICN, MBM); idem, 18 January 1994, J. Stehmann \& A.Vieira 1295 (UEC); Urubici, Topo do Morro da Igreja, próximo do Cindacta, 4 January 1995, J. Stehmann \& A. 
Vieira 1295 (FLOR); Serra do Oratório, 10 km E de Bom Jardim da Serra, ca. 1200 m, 16 January 1957, L. Smith \& R. Reitz 10151 (CTES, MBM, US); Curral Falso, Bom Jardim, São Joaquim, 19 February 1959, R. Reitz \& R. Klein 8419 (HBR, US); Desfiladeiro do Funil, Bom Jardim da Serra, January 1986, M. Sobral 4830 (F, MBM); Beira da estrada SC 439, em direção a Grão Pará, Serra do Corvo Branco, 12 January 1987, D. Falkenberg, P. Berry \& L. Brako 4320 (FLOR, ICN, MBM); Mun. Grão Pará, Encosta leste da Serra do Corvo Branco, 27 February 1996, J. Jarenkow \& M. Sobral 3073 (FLOR); Serra do Oratório, Bom Jardim, 9 December 1958, R. Reitz \& M. Klein 7688 (MO, US); Campo dos Padres, Fazenda da Sra. Sonia Munareto, campo na borda Leste do cânion do Espraiado, 27 April 2006, M. Souza, A. Zanin, H. Longhi-Wagner \& M. Rieper 1592 (FLOR); Urubici, Parque Nacional de São Joaquim, 12 December 2014, R. Trevisan 1607 (FLOR); Parque Nacional São Joaquim, subida para o Morro da Igreja 49²8'53.3" W 2807’35.2 S, 24 January 2018, J.Pastore, J. Florentin \& M. Nuñez Florentin 5462 (CTBS, CTES).

\section{DISCUSSION}

The descriptions of G. boliviana, G. gertii, G. guaranitica, and G. reitzii are complemented by traits not previously described, principally those of the fruit and seeds. Based on our morphological analysis we can confirm the positioning of G. boliviana in the Galianthe subg. Ebelia mainly because of their septicidal capsules with indehiscent mericarps. Also we can confirm the positioning of other three species in the Galianthe subg. Galianthe, as was proposed by Cabral (Cabral \& Bacigalupo 1997, 2000, Cabral; 2005; 2009), because of its septicidal capsules with dehiscent valves.

\section{ACKNOWLEDGEMENTS}

JEF and MNF gratefully acknowledge the Consejo Nacional de Investigaciones Científicas y Tecnológicas (CONICET) for grant support. The author JFBP thanks CNPq for fellowship support (Grant n. 302452/2017-6).We are grateful to Laura Simón for the preparation of illustrations; to Michelle Mota for the assistance during the field work in Santa Catarina; and to Elsa Leonor Cabral for the valuable suggestions on improving the manuscript. We also greatly indebted to the anonymous reviewers and editor who largely contributed for improving this paper.

\section{REFERENCES}

Bachman, S., Moat, J., Hill, A., de la Torre, J. \& Scott, B. (2011) Supporting Red List threat assessments with GeoCAT: Geospatial Conservation Assessment Tool. ZooKeys 150: 117-126.

https://doi.org/10.3897/zookeys.150.2109

Cabral, E.L. (1991) Rehabilitación del género Galianthe (Rubiaceae). Boletín de la Sociedad Argentina de Botánica 27 (3-4): $235-249$.

Cabral, E.L. (1993) Novedades en Galianthe (Rubiaceae). Bonplandia 7 (1-4): 1-29.

Cabral, E.L. (2005) Notes on Galianthe (Spermacoceae, Rubiaceae) in the Bolivian flora. Brittonia 57 (2): 141-149. https://doi.org/10.1663/0007-196X(2005)057[0141:NOGSRI]2.0.CO;2

Cabral, E.L. (2009) Revisión sinóptica de Galianthe subgen. Galianthe (Rubiaceae: Spermacoceae), con una sección nueva. Annals of the Missouri Botanical Garden 96: 27-60. https://doi.org/10.3417/2006193

Cabral, E.L. \& Bacigalupo, N.M. (1997) Revisión del género Galianthe subg. Ebelia stat. nov. (Rubiaceae: Spermacoceae). Annals of the Missouri Botanical Garden 84: 857-877. https://doi.org/10.2307/2992031

Cabral, E.L. \& Bacigalupo, N.M. (2000) Novedades Taxonómicas en Galianthe y Borreria (Rubiaceae-Spermacoce). Bonplandia 10 (1-4): 119-128.

Carmo, M.A.J., Salas, R. \& Simões, A.O. (2016) An updated description of Galianthe vaginata (Spermacoceae, Rubiaceae), a species endemic to the Serra da Mantiqueira and Serra do Mar, Southeast Brazil. Phytotaxa 258 (1): 89-94. https://doi.org/10.11646/phytotaxa.258.1.7

Chodat, R.H. \& Hassler, É. (1904) Plantae Hasslerianae II. Bulletin de l’Herbier Boissier, 2me. Sér. 4: 188-189. 
Daviña, J. \& Cabral, E.L. (1991) Recuentos cromosómicos en Galianthe (Rubiaceae). Boletín de la Sociedad Argentina de Botánica 27 (3-4): 250-252.

Delprete, P.G. (2004) Galianthe. Rubiáceas, Vol. 1 - Gêneros de A-G: 1. Alseis até 19. Galium. In: Reis, A. (Ed.) Flora Ilustrada Catarinense Herbário Barbosa Rodrigues, Itajaí, pp. 213-272.

Dessein, S. (2003) Systematic studies in the Spermacoceae (Rubiaceae). Unpublished Ph.D. Thesis, Katholieke Universiteit Leuven, Leuven.

Florentín, J.E., Nuñez Florentín, M. \& Cabral, E.L (2017a) A synopsis of Galianthe (Rubiaceae) in Rio Grande do Sul, Southern Brazil, and a new endemic species from Serra Geral. Acta Botanica Brasilica 31: 619-638. https://doi.org/10.1590/0102-33062017abb0135

Florentín, J.E., Cabaña Fader, A.A., Salas, R.M., Janssens, S., Dessein, S. \& Cabral, E.L. (2017b) Morphological and molecular data confirm the transfer of homostylous species in the typically distylous genus Galianthe (Rubiaceae), and the description of the new species Galianthe vasquezii from Peru and Colombia. PeerJ 5: e4012.

https://doi.org/10.7717/peerj.4012

Florentín, J.E., Arana, D.M., Prado, D.E., Morrone, J.J. \& Salas, R.M. (2018) Diversification of Galianthe species (Rubiaceae) in the Neotropical seasonally dry forests: a case study of a mainly subshrubby genus. Plant Ecology and Evolution 151 (2): 161-174. https://doi.org/10.5091/plecevo.2018.1419

Galati, B.G. (1988) Estudios embriológicos en la tribu Spermacoceae (Rubiaceae). Unpublished Doctoral thesis, Universidad de Buenos Aires, Buenos Aires.

Google Earth Pro (2018) Available from: https://www.google.com.ar/intl/es/earth/ (accessed 5 March 2018)

Govaerts, R. (1996) World checklist of seed plants, Vol. 2, part 1. Continental Publishing, Antwerp, 492 pp.

Grisebach, A.H.R. (1879) Galianthe. Abhandlungen der Königlichen Gesellschaft der Wissenschaften zu Göttingen 24: 156.

Hijmans, R.J. (2015) DIVA-GIS, a geographic information system for the analysis of biodiversity data. Version 7.5. Available from: http:// www.diva-gis.org/ (accessed 17 July 2018)

Instituto Brasilero do Meio Ambiente (Ibama) (1998) Unidades de conservação Federais em Santa Catarina, Brasil. Parque Nacional de São Joaquim, Ibama, SC, pp. 4-5.

IUCN Standards and Petitions Subcommittee (2014) Guidelines for Using the IUCN Red List Categories and Criteria. Version 11. Prepared by the IUCN species survival commission. IUCN Council, Gland, Switzerland and Cambridge, UK, 87 pp. Available from: http://www.iucnredlist.org/documents/RedListGuidelines.pdf (accessed 18 July 2018)

Kårehed, J., Groeninckx, I., Dessein, S., Motley, T.J. \& Bremer, B. (2008) The phylogenetic utility of chloroplast and nuclear DNA markers and the phylogeny of the Rubiaceae tribe Spermacoceae. Molecular Phylogenetics and Evolution 49: 843-66. https://doi.org/10.1016/j.ympev.2008.09.025

Külkamp, J., Heiden, G. \& Iganci, R.J. (2018) Endemic plants from the Southern Brazilian Highland Grasslands. Rodriguésia 69 (2): 429-440. https://doi.org/10.1590/2175-7860201869214

Kunth, K.S. (1817) Alnus acuminata. Nova Genera et Species Plantarum vol. 2. La Librairie Grecque-Latine-Allemande, Paris, p. 20.

Kuntze, O. (1898) Revisio genera plantarum vol. 3, pars 2. A. Felix [etc.], Leipzig, pp. 1-202.

Mocochinski, A.Y. \& Scheer, M.B. (2008) Campos de altitude na Serra do mar paranaense: aspectos florísticos. Floresta 38 (4): $625-$ 640.

https://doi.org/10.5380/rf.v38i4.13158

Moore, S. (1904) Mons. A. Robert's Matto Grosso plants. II. Journal of Botany 42: 100-110.

Pire, S.M. \& Cabral, E.L. (1992) El valor del polen en la revalidación de Galianthe (Spermacoceae-Rubiaceae). Darwiniana 31: 1-10.

Porto, M.L., Jacques, S.M.C., Miotto, S.T., Waechter, J.L. \& Detoni, M.L. (1977) Tribu Spermacoceae (Rubiaceae). Flora Rio Grande do Sul. Boletim do Instituto Central de Biociencias, Série Botanica 5: 1-144.

Schumann, K. (1888) Rubiaceae, Tribus VIII. Spermacoceae. In: von Martius, C.F.P., Eichler, A.G. \& Urban, I. (Eds.) Flora Brasiliensis, vol. 6, pars 6. Fleisher, Leipzig, pp. 5-102.

Smith, L.B. \& Downs, R.J. (1956) Resumo preliminar das Rubiaceas de Santa Catarina. Sellowia 7: 1-86.

Standley, P.C. (1931) Studies of American Plants V. Field Museum of Natural History Botanical series 8 (5): 392-1395.

Terrel, E.E. \& Wunderlin, R.P. (2002) Seed and fruit characters in selected Spermacoceae and comparison with Hedyotideae (Rubiaceae). Sida 20: 549-557.

Thiers, B. (2018) Index herbariorum: a global directory of public herbaria and associated staff. New York Botanical Garden's Virtual Herbarium. https://doi.org/10.3897/biss.2.26440

Turland, N.J., Wiersema, J.H., Barrie, F.R., Greuter, W., Hawksworth, D.L., Herendeen, P.S., Knapp, S., Kusber, W.-H., Li, D.-Z., Marhold, K., May, T.W., McNeill, J., Monro, A.M., Prado, J., Price, M.J. \& Smith, G.F. (Eds.) (2018) International Code of Nomenclature for 
algae, fungi, and plants (Shenzhen Code) adopted by the Nineteenth International Botanical Congress Shenzhen, China, July 2017. Regnum Vegetabile, vol. 159. Koeltz Botanical Books, Glashütten.

https://doi.org/10.12705/Code.2018

Zappi, D., Jardim, J., Bezerra de Souza, E., Régis Di Maio, F., Barbosa, M.R., Mouço Valente, A.S., Ferreira dos Santos Filho, L.A., Pougy Monteiro, N. (2013) Rubiaceae. In: Martinelli, G. \& Moraes, M.A. (Eds.) Livro Vermelho da Flora do Brasil. Centro Nacional de Conservação da Flora, Rio de Janeiro, pp. 922-941. 